\title{
Phyllanthus amarus Schum Dan Bioaktivitasnya
}

\author{
Marina Silalahi ${ }^{1)}$ \\ ${ }^{1}$ Prodi Pendidikan Biologi, Fakultas Keguruan dan Ilmu Pendidikan, Universitas Kristen Indonesia \\ Email: marina_biouki@yahoo.com; marina.silalahi@uki.ac.id
}
APA Citation: Silalahi, M. (2020). Phyllanthus amarus Schum Dan Bioaktivitasnya. Quagga: Jurnal Pendidikan dan Biologi, 12(1), 44-51. doi: 10.25134/quagga.v12i1.2147.

Received: 20-11-2019

Accepted: 07-01-2020

Published: 24-01-2020

\begin{abstract}
Abstrak: Phyllantus amarus Schum (PA) merupakan salah satu tumbuhan obat yang telah lama digunakan untuk mengatasi gangguan ginjal khususnya sebagai peluruh batu ginjal. Berbagai penelitian telah dilakukan untuk melihat hubungan pemanfaatan tumbuhan sebagai obat tradisional berhubungan dengan senyawa bioaktif dan bioaktivitasnya.Penulisan artikel ini didasarkan pada studi literatur pada berbagai artikel ilmiah, buku yang terbit secara online maupun offline, kemudian disintesis untuk menjelaskan bioaktivitas PA. PA merupakan salah satu spesies dari famili Phyllantaceae, yang sangat mudah ditemukan diberbagai habitat di Indonesia dan cenderung dianggap sebagai gulma. Walupun PA mudah ditemukan, namun PA juga telah diperjual-belikan oleh pedagang tumbuhan obat di pasar Kabanjahe, Sumatera Utara. Secara etnobotani PA digunakan untuk mengatasi diabetes mellitus, hipertensi, analgesik, malaria, mengatasi batu ginjal, dan diare.PA mengandung senyawa filantin, hipofilantin, filantenol, nirantin, nirurin, kuersetin, rutin, asam galat, isokuersetin dan asam lemak.PA memiliki bioaktivitas sebagai hepetoprotektor, anti disentri, antioksidan, anti kanker dan tumor, dan anti batu ginjal. Pemanfaatan PA sebagai antikanker perlu diteliti lebih lanjut terutama dosis dan cara pemanfaatannya, sehingga dapat digunakan sebagai obat alternatif dalam penyembuhan penyakit kanker.
\end{abstract}

Kata Kunci: Phyllanthus amarus; filantin; anti kanker.

Abstract: Phyllantus amarus Schum (PA) is a medicinal plant that has long been used to treat kidney disorders especially as a peluruh kidney stones. A lot of the research have been conducted to know the relationship between the uses to bioactive compounds and its bioactivity. This article is based on review of the various scientific articles, books published online and offline, then synthesized to explain of PA bioactivity. PA is a species belonging Phyllantaceae, which is very easily found in some habitats in Indonesia and considered a weed. Although PA is easy to found, the PA has also been traded by traders of medicinal plants in Kabanjahe market, North Sumatra. Ethnobotany of PA have been used to cure of diabetes mellitus, hypertension, analgesic, malaria, kidney stones, and diarrhea. PA has the filantin, hypophilantin, philanthenol, nirantin, nirurin, quercetin, routine, gallic acid, isoku citrine and fatty acids. PA has bioactivity as hepetoprotector, anti diabetes mellitus, anti dysentery, antioxidant, analgesic, anti cancer and tumor, and anti kidney stone. The use of PA as an anticancer needs to be further investigated, especially the dosage and method of its use, so that it can be used as an alternative medicine to cure cancer.

Keywords: Phyllanthus amarus; filantin; anti-cancer.

\section{PENDAHULUAN}

Phyllanhtus amarus (PA) atau yang lebih dikenal dengan namaPhyllanthus niruri merupakan salah satu tumbuhan obat yang telah lama digunakan untuk mengatasi gangguan ginjal khususnya sebagai peluruh batu ginjal. Secara empirik terlihat bahwa PA sangat mudah ditemukan diberbagai habitat di Indonesia dan cenderung dianggap sebagai
gulma.Oleh etnis Batak PA disebut sebagai siraprap dan telah lama digunakan untuk mengatasi hipertensi dan batu ginjal (Silalahi, 2014; Silalahi et al., 2015), dan merupakan salah satu jenis tumbuhan obat yang telah diperjual-belikan di pasar Kabanjahe Sumatera Utara (Silalahi et al., 2015).

Walaupun tumbuhan telah lama dimanfaatkan sebagai obat tradisional, namun 
berbagai kelompok masyarakat masih terutama dari pengobatan modern masih meragukan khasiatnya karena dianggap belum memiliki bukti ilmiah yang memadai. Fabricant dan Fansworth (2001) menyatakan bahwa sekitar $80 \%$ pengembangan obat modern didasarkan pada pemanfaatannya oleh masyarakat lokal. Bila ditelusur lebih lanjut memang berbagai bukti ilmiah pemanfaatan tumbuhan obat sering terpisah satu sama lain, sehingga untuk mendapatkan informasi yang komprehensif dibutuhkan waktu yang lama.

Phyllanthus amarus mudah dan banyak ditemukan di daerah tropis(Asare et al., 2012) termasuk Indonesia.Sebagai obat tradisional PA digunakan untuk mengatasi hiperglikemia, hipertensi (Asare et al., 2012; Bagalkotkar et al., 2006), mengurangi rasa sakit, malaria (Asare et al., 2012), dan anti hepetitis B (Bagalkotkaret al., 2006; Calixto et al., 1998)), anti-hepatotoksik, anti-lithik, anti-HIV (Bagalkotkar et al., 2006), infeksi usus (Calixto et al., 1998), ginjal, liver dan berbagai penyakit kelamin, ekspektorat dan mengatasi diare (de Padua et al., 1999).

Khasiat tumbuhan dalam pengobatan berhubungan dengan kandungan senyawa bioaktifnya yang terlibat secara langsung maupun tidak langsung dalam proses metabolisme tubuh. Sebagai contoh senyawa yang berfungsi sebagai anti diabetes melitus merupakan senyawa yang menghambat metabolisme karbohidrat sedangkan hepatoprotektor merupakan senyawa yang dapat memperbaiki fungsi hati (Munim dan Hanani, 2010). Khasiat tumbuhan obat sangat dipengaruhi oleh berbagai faktor antara lain dosis dan ketepatan bahan. Anggapan bahwa obat tradisional lebih aman dibandingkan obat sintetis diperlukan dosis yang tepat, karena pada dosis yang berlebihan akan bersifat toksik. Pengetahuan toksisitas sangat penting untuk mengetahui keamanan dari tumbuhan obat yang digunakan.Untuk memberikan informasi yang komprehensif mengenai pemanfaatan tumbuhan sebagai obat tradisional perlu didukung dengan bukti imiah khususnya hubungan kandungan metabolit sekundernya maupun bioaktivitasnya.

\section{METODOLOGI PENELITIAN}

Artikel ini ditulis berdasarkan studi literatur yang diperoleh secara on-line maupun offline.Artikel on-line didasarkan pada jurnal ilmiah yang diunduh dari google scholar, jurnal, maupun scopus, sedangkan off line didasarkan pada buku ataupun tesis maupun karya ilmiah lainnya.Hasil yang diperoleh disintesis sehingga diperoleh informasi sesuai dengan tujuan penulisan artikel.

\section{HASIL DAN PEMBAHASAN Botani}

Phyllanthus amarus Schum sinonim dengan $P$. swarzii, $P$. nanus, $P$. niruri $\mathrm{L}$. merupakan salah satu anggota dari famili Euphorbiaceae (de Padua et al., 1999). Sinonim merupakan spesies yang sama namum memiliki nama ilmiah yang berbeda. Famili Euphorbiaceae memiliki sekitar 300 genus dengan 7500 spesies yang tersebar di daerah tropis dan sub tropis (de Padua et al., 1999; Congruist 1981). Phylanthus merupakan salah satu genus utama dalam famili Euphorbiaceae yang memilki sekitar 400 spesies (Congruist, 1981) - 700 spesies (de Padua et al., 1999). Di Indonesia PA sangat mudah ditemukan dan menjadi salah satu gulma yang dilahan pertanian bahkan ditemukan di pinggir jalan, dan pekarangan.

Phyllanthus amarus sinonim dengan $P$. niruri, namun oleh berbagai masyarakat ilmiah di Indonesia lebih sering dikenal dengan nama $P$. niruri, sehingga diberbagai buku maupun artikel ilmiah lebih banyak menuliskan dengan $P$. niruri, sehingga dalam kajian ini $P$. niruri disamakan dengan PA karena tanaman tersebut merupakan sinonim. Bagi masyarakat lokal Indonesia PA dikenal dengan nama antara lain meniran (Sunda), meniran (Jawa), gasou ma dungi (Ternate) (de Padua et al., 19), sidukung anak (Mandailing), siraprap (Karo) (Silalahi 2014). Vernaculer name untuk Pn antara lain dukung anak (Malaysia), manjinimbi (Papua Nugini), herbe au chagin (Francis), sampasampalukan (Tagalok) (de Padua et al., 1999).

Berdasarkan asal-usulnya PA merupakan tanaman native Amerika (de Padua et al., 1999), namun sudah ditemukan di seluruh kawasan Malesia dan sangat mudah ditemukan 
di Indonesia.Masyarakat lokal Indonesia telah lama memanfaatkan PA sebagai obat tradisional dan telah terdaftar dalam Materia Medica Jilid II dan digunakan sebagai anti diuretik (, bahkan telah diperjual-belikan oleh pedagang tumbuhan obat di pasar Kabanjahe sebagai obat untuk mengatasi batu ginjal (Silalahi et al., 2015).Beberapa spesies yang termasuk dalam genus Phyllanthus telah digunakan sejak 2000 tahun oleh India dan telah tercatat dalam sistem pengobatan tradisional Ayurveda, Siddha dan Unani (de Padua et al., 1999).

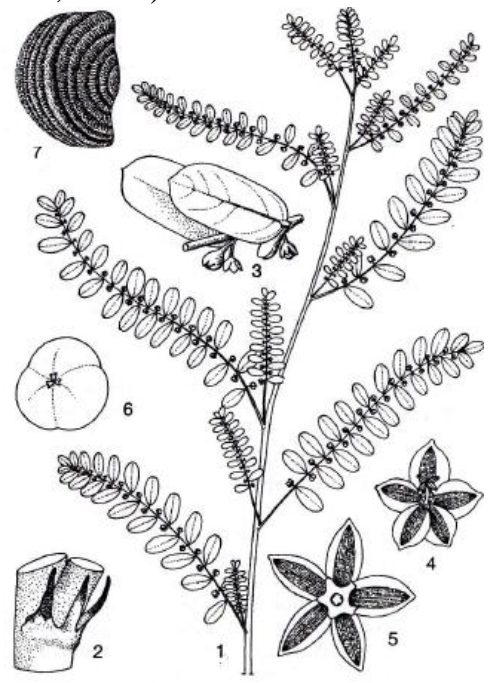

Gambar 1. Phyllanthus amarus Schum. 1. Habitus, 2. Katafil dan stipula, 3.Daun dengan pembungaan, 4.Bunga jantan, 5.Bunga betina,

6. Buah, 7. Biji (de Padua et al. 1999).

Secara morfologi PA memiliki ciri-ciri antara lain herba monoecius, annual dan tegak. Tinggi PA dapat mencaai $60 \mathrm{~cm}$ dengan percangan phylantoid, cataphyll subulate dengan stipula triangular yang dapat berubah menjadi warna hitam.Cabang bersifat deciduous dengan panjang 4-12 $\mathrm{cm}$ dengan jumlah daun 15-30. Daun subsesil berbentuk elliptical-oblong denga ukuran 5-11 mm x 3-6 $\mathrm{mm}$ dengan bagian basal obtuse atau rounded dan bagia apeks apiculata. Bunga bewarna merah muda sering juga bewarna kemerahan dengan 5-6 kalis berlobus. Buah merupakan buah kapsul dengan ukuran 1,8-2,5 mm, obtusely trigonomous, halus dengan biji yang berbentuk longitudinal. Tanaman ini bisa ditemukan hingga ketinggian $1000 \mathrm{~m}$ dpl (de Padua et al., 1999) (Gambar 1).

\section{Bioaktivitas}

Secara etnobotani PA digunakan untuk mengatasi berbagai penyakit seperti hiperglikemia, hipertensi (Asare et al., 2012; Bagalkotkar et al., 2006; de Padua et al., 1999), hepatoprotektor (Bagalkotkar et al., 2006; de Padua et al., 1999; Amin et al., 2011) mengurangi rasa sakit, malaria (Asare et al., 2012), anti hepetitis B (Bagalkotkar et al., 2006; Calixto et al., 1998), hepatoprotektor, anti-HIV (Bagalkotkar et al., 2006), infeksi usus (Calixto et al., 1998), penyakit kelamin, ekspektorat, dan diare (de Padua et al., 1999). Berdasarkan kajian yang kami lakukan PA memiliki bioaktivitas sebagai hepetoprotektor, anti diabetes mellitus,

anti disenteri, antioxidant, analgesik, anti kanker, tumor, dan anti batu ginjal.

\section{Anti Kanker dan Tumor}

Kanker merupakan penyakit yang disebabkan pertumbuhan sel yang tidak terkendali, oleh karena itu senyawa anti kanker merupakan senyawa yang berfungsi menghambat pertumbuhan atau mengganggu pembelahan sel. Kemampuan senyawa untuk menginduksi apostosis merupakan marker penting senyawa yang bersifat sebagai agent anti tumor (Junior et al., 2012). Penghambatan pertumbuhan sel dapat dilakukan dengan menghambat pembentukan benang spindel mitosis dan mengakibatkan kematian sel (apostosis) (Tang et al., 2010; Junior et al., 2012). Apoptosis merupakan proses selluler yang mengakibatkan kematian sel tanpa inflamasi dengan serangkaian proses yang menyebabkan: kondensasi kromatin, desintegrasi nukleus, reduksi volume sel dan meningkatnya densitas sel (Junior et al., 2012).

Cara penghambatan atau perusakan sel oleh senyawa anti kanker berbeda-beda, namun biasanya hanya toksik pada sel kanker dan tidak toksik pada sel normal lainnya seperti yang ditunjukkan oleh ekstrak Phyllanthus (Tang et al., 2010; Junior et al., 2012).Phyllanthus telah lama digunakan secara tradisional sebagai anti tumor (Zheng et al., 2016) karena dapat menginduksi apostosis (Tang et al., 2010). Ekstrak PA mampu menghambat pertumbuhan 
sel kanker melanoma, prostat (Tang et al., 2010), sel karsinoma hepatoselluler, sel karsinoma korektal dan keratinosit (Junior et al., 2012). Ekstrak Phylanthus menyebabkan pembentukan sebuah clear "ladder" fragmentation apoptotic DNA pada gel agarose yang ditunjukkan dengan peningkatan aktivitas caspase-3 dan -7.Phyllanthus menginduksi penahan (arrest) fase Go/G1 pada sel PC-3 dan penahanan fase $S$ dan disertai dengan akumulasi sel pada fase sub-G1 (apoptosis) (Tang et al., 2010).

Ethyl brevifolincarboxylate dan corilagin merupakan senyawa anti tumor yang telah berhasil diioslasi dari PA memiliki spektrum luas sebagai anti tumor dan toksistas yang lebih rendah pada sel normal (Zheng et al., 2016).Phyllanthus menghambat pertumbuhan sel kanker secara selektif melalui modulasi siklus sel dan induksi apostosis melalui aktivasi caspases di dalam sel kanker melanoma dan prostat (Tang et al., 2010). Sel colorectal carcinoma (HT29) dan human hepatocellular carcinoma (HepG2) ditreatmen dengan spraydried extracts PN (SDEPN) saja atau kombinsai dengan cisplatin dengan konsentrasi (0.5 $\mathrm{mg} / \mathrm{mL}$ dan $1 \mathrm{mg} / \mathrm{mL}$ ) memiliki aktivitas sebagai anti kanker dengan efek yang berbedabeda. Pada sel HT29, yang pretreatment dengan SDEPN dan selanjutnya dengan cisplatin menghasilkan lebih keatian sel. Sel HepG2 menunjukkan kematian sel yang signifikan dengan treatmen SDEPN dan dikombinasikan dengan cisplatin. SDEPN dan kombinasinya dengan cisplatin menginduksi peningkatan sinergis dalam kematian sel sel HT29 dan HepG2 (Júnior et al., 2012)

\section{Gangguan Ginjal}

Ginjal merupakan organ yang berfungsi untuk menyaring sennyawa yang tidak diperlukan oleh tubuh dan mengaur keseimbangan cairan tubuh (Munin dan Hanani, 2010), dan berbagai senyawa yang masuk ke dalam tubuh dapat mengakibatkan gangguan pada ginjal.Batu ginjal merupakan salah satu gangguan pada ginjal yang sering ditemukan pada manusia terutama laki-laki. PA disebut juga sebagai 'stone breaker' oleh indogenous etnis di Amazone karena sangat efektif sebagai obat untuk menghilangkan batu empedu dan batu ginjal (Júnior et al., 2012). Beberapa kondisi yang dapat menyebabkan batu ginjal antara lain hiperkalsiuria, penyakit gout atau asam urat, peradangan usus besar dan komsumsi antasida (Munim dan Hanani 2010). Pemberian ekstrak air PA melalui oral selama 30 hari dengan dosis 50, 150, atau 250 $\mathrm{mg} / \mathrm{kgtidak}$ menunjukkan aktvitas genotoksik, antigenotoksis, dan sitotoksik (de Queiroz et al., 2013).

Tikus yang diberi ekstrak air PA (1,25 $\mathrm{mg} / \mathrm{mL} /$ hari) secara oral selama 42 hari menunjukkan creatinine clearance atau konsentrasi urinari dan $\mathrm{Na}^{+}, \mathrm{K}^{+}, \mathrm{Ca}^{2+}$, oksalat, posfat dan asam urat tidak dideteksi atau menginduksi lithiasis. Pemberian PA menghambat pertumbuhan matrix calculus dan mereduksi jumlah stone satellites (Freitas et al., 2002) dan sebagian besar senyawa anti batu ginjal bersifat diuretik (Munim dan Hanani 2011). Ektrask PA tidak menghambat presipitasi kalsium oksalat dan jumlah kristal diperoleh semakin banyak, namun secara signifikan lebih kecil dibanding urine kontrol. Pertumbuhan kristal $\mathrm{CaOx}$ sebagai tahap awal dari pembentukan batu ginjal, untuk mencegahnya dapat digunakan ekstrak PA.

\section{Hepatoprotektor}

Hati atau liver merupakan organ vital yang berfungsi tempat pembentukan asam empedu, menjaga ketersediaan gula darah, tempat metabolisme senyawa yang masuk ke dalam tubuh, dan pembentukan lemak (Munin dan Hanani, 2011), oleh karena liver berperan untuk metabolisme zat yang berasal dari eksogen, mengatur proteksi dan detoksifikasi tubuh dari substansi asing yang masuk ke dalam tubuh (Saleem et al., 2010). Hepatoprotektor merupakan istilah yang digunakan untuk obat atau senyawa yang melindungi atau memulihkan fungsi hati seperti perlemakan, sirosis dan kanker hati (Munin dan Hanani, 2011).

Gangguan liver seperti sirosis dapat diobati dengan berbagai jenis tumbuhan obat termasuk PA (Amin et al., 2012). Hati dapat beregenarasi melalui sel hepatosit, sel epitel biliari, dan sel endotel (Munin dan Hanani 2011). Aktivitas sebagai hepatoprotektor sebagian dihubungkan dengan dengan kemapuannya sebagai 
antioksidan. Aktivitas PA sebagai hepatoprotektif telah dilaporkan (Amin et al., 2012). PA mengandung senyawa filantin, hipofilantin, filantenol, nirantin, nirurin, kuersetin, rutin, asam galat, isokuersetin dan asam lemak.Filantin dan hipofilantin diduga sebagai seyawa yang bersifat sebagai hepatoprotektor oleh karena itu filantin dijadikan sebagai marker pada sediaan yang mengandung meniran (Munin dan Hanani 2011)

Thioacetamide (TAA) (Amin et al., 2012) dan senyawa $\mathrm{CCl}_{4}$ merupakan senyawa yang digunakan dalam laboratorium sebagai hepatoksikan pada liver.TAA yang mengakibatkan konversi metabolik liver ke arah metabolik yang menghasilkan radikal bebas seperti thioacetamide sulfoxide, thioacetamide-S, dan S-dioxide (Amin et al., 2012), sedangkan senyawa $\mathrm{CCl}_{4}$ menginduksi hepatoksisitas melalui peningkatan aktivitas enzim glutamate oxaloacetate transaminase (GOT) dan glutamate pyruvate transaminase (GPT). Ekstrak PA memiliki aktivitas melawan sirosis hati yang diinduksi oleh TAA pada tikus (Amin et al., 2012). Hasil penelitian menunjukkan bahwa lima kelompok tikus diberi perlakuan yang berbeda yaitu kontrol, TAA, silymarin, PA dosis tinggi, dan PA dosis rendah memiliki perbedaan signifikan antara kelompok TAA dan kelompok lainnya dalam level atau tingkatan berat badan, berat liver, parameter biokimia liver, kapasitas total antioksidan, peroksidasi lipid, enzim stres oxidative (Amin et al., 2012). Secara visual terindikasi granula kasar pada permukaan liver tikus hepatoksik dan sangat berbeda permukaan halus liver pada tikus yang diberi silymarin dan PA.Histopathologi liver yang hepatooksik menunjukkan adanya necrosis, infiltrasi limposit pada daerah centrilobular, dan poliferasi jaringan ikat fibrous pada liver tikus hepatotoksik (Amin et al., 2012). Liver yang ditreatment dengan PA menunjukkan inflammation minimum dan bentuk lobular liver normal (Amin et al., 2012).

Pemberian ekstrak PA pada tikus yang mengalami hepatatoksik (ditreatment dengan senyawa $\mathrm{CCl}_{4}$ ) dapat mencegah aktivitas enzim glutamate oxaloacetate transaminase (GOT) dan glutamate pyruvate transaminase (GPT). Amin et al., (2013) menyatakan bahwa ektrak PA dapat menormalkan ROS yang disebabkan adanya senyawa 4-O-caffeoylquinic acid dan quercetin 3-O-rhamnoside yang dihasilkan PA. Tikus diinjeksi secara intraperitonal dengan TAA dengan konsentrasi, $200 \mathrm{mg} / \mathrm{kg}$ dengan frekuensi tiga kali seminggu) selama 8 minggu dan kemudian setiap hari diberi dengan ekstrak PA $(200 \mathrm{mg} / \mathrm{kg})$ secara oral selama 8 minggu menurunkan efek toksik dari TAA (Amin et al., 2013).

\section{Anti Disentri}

Disentri merupakan salah satu jenis penyakit diare akut yang disebabkan oleh bakteri Shigella dysentriae. Berbagai kasus menunjukkan resistensi $S$. dysenteriae terhadap beberapa antibiotik semakin meningkat, oleh karena itu mencari senyawa bioaktif yang menghambat pertumbuhan bakteri karena dianggap lebih efektif, efisien, dan aman. Phyllanthus niruri memiliki aktivitas antibakteri (Munfaati et al., 2015). Pemberian ekstrak PA dengan konsentrasi 20\%, 40\%, $60 \%, 80 \%, 100 \%$, kontrol negatif (akuades), dan kontrol positif (kloramfenikol) menunjukkan bahwa ekstrak etanol PA dapat menghambat pertumbuhan $S$. dysentriae secara signifikan. Terdapat hubungan antara peningkatan konsentrasi ekstrak $P$. niruri dengan penurunan jumlah koloni $S$. dysenteriae. Nilai MIC (minimum inhibitory concentration) ekstrak etanol PA terhadap $S$. dysenteriae adalah $20 \%$ dan nilai MBC (minimum bactericidal concentration) adalah 60\% (Munfaati et al., 2015).

\section{Antioksidan}

Senyawa antioksidan merupakan senyawa yang dapat menghambat pembentukan radikal bebas atau menghambat stress oksidatif. Stres oksidatif merupakan gangguan keseimbangan antara prooksidan dan antioksidan yang meningkat di berbagai organ, jaringan, dan sel yang muncul sebagai hasil dari peningkatan produksi reaktif oksigen spesies (ROS) atau penurunan tingkat antioksidan pertahanan (Sarkar et al., 2010). Pada kondisi fisiologis normal, sekitar $1-4 \%$ oksigen seluler yang dikonsumsi mitokondria, diubah menjadi anion superoksida $\left(\mathrm{O}^{-2}\right)$, hidrogen peroksida $\left(\mathrm{H}_{2} \mathrm{O}_{2}\right)$, 
dan hidroksil radikal (OH) (Sarkar et al., 2010). Radikal bebas akan bereaksi dengan makromolekul seluler dan menyebabkan kerusakan jaringan peroksidatif (Dalle-Donne et al., 2003). Ketika produksi ROS melebihi yang digunakan, tubuh membutuhkan suplemen antioksidan dari luar, untuk mengatasi kelebihan ROS (Sarkar et al., 2010). Oxidative stress dihasilkan dari ketidakseimbangan antara sistem radical generating and radicalscavenging yang meningkatkan produksi reactive oxygen species (ROS) atau mereduksi aktivitas pertahanan antioxidant (Maritim et al., 2003).

Kemampuan PA sebagai antioksidan telah dilaporkan oleh Sarkar dan Sil (2010), Amin et al., (2011), dan Raphael dan Kuttan 2003). Kemampuan PA sebagai antioksidan dihubungkan dengna kandungan senyawa fenoliknya, polyphenols (Giribabu et al., 2014) dan tannin (Raphael dan Kuttan 2003). Sarkar et al., (2010) melaporkan bahwa fraksi kasar ekstrak air $P$. niruri memiliki aktivitas antioksidan dan pemberian oral pada konsentrasi yang sama memiliki aktivitas yang lebih baik dibandingkan secara intraperitonal (Sarkar et al., 2008). Penghambatan ROS ekstrak air dan buah dari PA lebih tinggi dibandingkan ekstrak metanol. Ekstrak air dan metanol PA memiliki potensi sebagai inhibitor dari microsomal lipid peroxidation yang diinduksi oleh $\mathrm{Fe}^{2+}$ dan ascorbate secara in vitro.

Perbedaan aktivitas antioksidan PA berhubungan dengan kandungan flavonoidnya. Kadar flavonoid PA dipengaruhi oleh pelarut yang digunakan. Ekstrak etanol PA menunjukkan kadar flavonoid $(123,9 \pm 0,002$

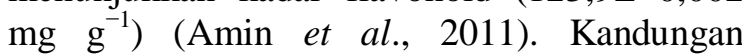
senyawa fenolik yang diperoleh dengan menggunakan ekstrak air buah Pn $(360 \mathrm{mg} / \mathrm{g})$ lebih tinggi dibandingkan dengan ekstrak metanol $(31,8 \mathrm{mg} / \mathrm{g})$. Kadar fenolik ekstrak metanol daun (105 mg/g) Pn hampir sama dengan ektrak air $(97 \mathrm{mg} / \mathrm{g})$.

Ekstrak air daun $P$. niruri menunjukkan aktivitas antioksidan secara in vitro dengan IC50 sedikit lebih rendah dibandingkan dengan asam askorbat. Scerening fitokimia $P$. niruri mengandung polyphenols (Giribabu et al.,
2014) dan tannin (Raphael dan Kuttan 2003) yang memiliki aktivitas sebagai antioksidan. Kemampuan ekstrask $P$. niruri sebagai antiokasidan dapat melindungi ginjal dari stress oksitatif yang sehingga dapat mencegah diabetes mellitus (Giribabu et al., 2014). Ekstrak metanol dari P. amarus 50, 200, and $1000 \mathrm{mg} / \mathrm{kg}$ berat badan secara signifikan menghambat lesi lambung, yang diinduksi dengan pemberian ethanol absolut ke dalam lambung $(8 \mathrm{ml} / \mathrm{kg})$. Analisis biokimia menunjukkan reduksi glutathione (GSH) pada mukosa lambung yang dihasilkan dari pemberian etanol secara signifikan dihambat dengan pemberian ekstrak PA. Ekstrak air dan metanol PA menghasilkan penghambatan odema tikus hingga $42 \%$ dibandingkan dengan kontrol pada jam ke 3 dan terus meningkat hingga jam ke 8. Aktivitas antioksidan dari ekstrak diduga berhubungan dengan senyawa tanin yang bertanggung jawab dalam aktivitas ini (Raphael dan Kuttan 2003).

\section{SIMPULAN}

Secara etnobotani PA digunakan untuk mengatasi diabetes mellitus, hipertensi, analgesik, malaria, mengatasi batu ginjal, dan diare. PA mengandung senyawa filantin, hipofilantin, filantenol, nirantin, nirurin, kuersetin, rutin, asam galat, isokuersetin dan asam lemak. PA memiliki bioaktivitas sebagai hepetoprotektor, anti disentri, antioksidan, anti kanker dan tumor, dan anti batu ginjal.

\section{REFERENSI}

Amin, Z.A., M. Bilgen, M.A. Alshawsh, H.M. Ali, A.H.A. Hadi, and M.A. Abdulla. 2012. Protective role of Phyllanthus niruri extract against thioacetamideinduced liver cirrhosis in rat model. Evidence-Based Complementary and Alternative Medicine 9 pages doi:10.1155/2012/241583: 1-10.

Amin, Z.A., M.A. Alshawsh, M. Kassim, H.M. Ali, and M.A. Abdulla. 2013. Gene expression profiling reveals underlying molecular mechanism of hepatoprotective effect of Phyllanthus niruri on thioacetamide-induced hepatotoxicity in Sprague Dawley rats. 
BMC Complementary and Alternative Medicine 13(160): 1-10.

Asare, G.A., K. Bugyei, A. Sittie, E.S. Yahaya, B. Gyan, S. Adjei, P. Addo, E.K. Wiredu, D.N. Adjei, and A.K. Nyarko. 2012. Genotoxicity, cytotoxicity and toxicological evaluation of whole plant extracts of the medicinal plant Phyllanthus niruri (Phyllanthaceae). Genetics and Molecular Research 11(1): 100-111.

Bagalkotkar, G., S.R. Sagineedu, M.S.Saad, and J. Stanslas. 2006. Phytochemicals from Phyllanthus niruri Linn. and their pharmacological properties: a review. Journal of Pharmacy and Pharmacology. 58: 1559-1570

Calixto, J.B., A.R.S. Santos, V.C. Filho, and R.A. Yunes. 1998. A review of the plants of the genus Phyllanthus: their chemistry, pharmacology, and therapeutic potential. Res Rev 18(4): 225-258.

Dalle-Donne, I., D. Giustarini, R. Colombo, R. Rossi, and A. Milzani. 2003. Protein carbonylation in human diseases. Trends in Molecular Medicine 9: 169176.

de Padua, L.S., and Bunyapraphatsara, R.H.M.J. Lemmens. $1999 . \quad$ Plant resources of South East Asia no 12(1). Backhuys Publishers, Leiden: 21-70.

de Queiroz, F.M., K.W.D.O. Matias, M.M.F. da Cunha, and A. Schwarz. 2013. Evaluation of (anti)genotoxic activities of Phyllanthus niruri L. in rat bone marrow using the micronucleus test. Brazilian Journal of Pharmaceutical Sciences 49(1): 135-148.

Fabricant, D.S., and N.R. Farnsworth. 2001. The value of plant used medicine for drug discovery. Enviromental Health Perspective 109(1): 69-75.

Freitas, A.M., N. Schor, and M.A. Boim. 2002. The effect of Phyllanthus niruri on urinary inhibitors of calcium oxalate crystallization and other factors associated with renal stone formation. BJU International 89: 829-834.
Giribabu, N., P.V. Rao, K.P. Kumar, S. Muniandy, S.S. Rekha, and N. Salleh. 2014. Aqueous Extract of Phyllanthus niruri Leaves Displays In Vitro Antioxidant Activity and Prevents the Elevation of Oxidative Stress in the Kidney of Streptozotocin-Induced Diabetic Male Rats. Evidence-Based Complementary and Alternative Medicine $10 \quad$ pages doi.org/10.1155/2014/834815: 1-11

Júnior, R.F.D.A., L.A.L. Soares, C.R.D.S. Porto, R.G.F. de Aquino, H.G. Guedes, P.R.Petrovick, T.P. de Souza, A.A. de Araújo, and G.C.B. Guerra. 2012a. Growth inhibitory effects of Phyllanthus niruri extracts in combination with cisplatin on cancer cell lines. World $J$ Gastroenterol 18(31): 4162-4168

Junior, R.F.D.A.J., T.P. de Souza, J.G.L. Pires, L.A.L. Soares, A.A. de Araujo, P.R. Petrovick, H.D.O. Macedo, A.L.C.D.S. Oliveira, and G.C.B. Guerra. 2012b. A dry extract of Phyllanthus niruri protects normal cells and induces apoptosis in human liver carcinoma cells. Experimental Biology and Medicine 237: 1281-1288.

Maritim, A.C., R.A. Sanders, and J.B. Watkins. 2003. Diabetes, oxidative stress, and antioxidants: a review. Journal of Biochemical and Molecular Toxicology 17(1): 24-38.

Munfaati, P.N., E. Ratnasari, and G. Trimulyono. 2015. Aktivitas Senyawa Antibakteri Ekstrak Herba Meniran (Phyllanthus niruri) terhadap Pertumbuhan Bakteri Shigella dysenteriae Secara in Vitro. Lentera Bio 4(1): 64-71

Munim, A., and E. Hanani. 2011. Fisioterapi Dasar. Dian Rakyat. Jakarta. viii + $356 \mathrm{hlm}$

Raphael, K.R., and R. Kuttan. 2003. Inhibition of experimental gastric lesion and inflammation by Phyllanthus amarus extract. Journal of Ethnopharmacology 87: 193-197. 
Saleem, T.S.M., C.M. Chetty, S. Ramkanth, V.S.T. Rajan, and K.M. Kumar, K Gauthaman. 2010. Hepatoprotective herbs a review. International Journal of Research in Pharmaceutical Sciences 1(1): 1-5.

Sarkar, M.K., and C.S. Parames. 2010. Prevention of tertiary butyl hydroperoxide induced oxidative impairment and cell death by a novel antioxidant protein molecule isolated from the herb, Phyllanthus niruri. Toxicology in Vitro 24: 1711-1719.

Silalahi, M. 2014. The ethnome- dicine of the medicinal plants in sub-ethnic Batak, North Sumatra and the conservation perspective, [Dissertation]. Indonesia, Universitas Indonesia.

Silalahi, M., Nisyawati, E.B. Walujo, J. Supriatna, and W. Mangunwardoyo. (2015). The local knowledge of medicinal plants trader and diversity of medicinal plantsin the Kabanjahe traditional market, North Sumatra, Indonesia. Journal of Ethnopharmacology 175: 432-443.

Tang, Y.Q., I.B. Jaganath, and S.D. Sekaran. 2010. Phyllanthus spp. induces selective growth inhibition of PC-3 and MeWo human cancer cells through modulation of cell cycle and induction of apoptosis. Plos One 5(9): e12644 PLoS ONE | www.plosone.org 